\title{
Community radio news coverage in the European media: mapping popular issues and important silences
}

\author{
Fábio Ribeiro \\ Universidade de Trás-os-Montes e Alto Douro \\ Universidade do Minho. Centro de Estudos de Comunicação e Sociedade \\ fabior@utad.pt
}

\author{
Submission date: February 2018 \\ Accepted date: March 2018 \\ Published in: June 2018
}

Recommended citation: RIBEIRO, F. (2018). "Community radio news coverage in the European media: mapping popular issues and important silences". Anàlisi. Quaderns de Comunicació i Cultura, 58, 13-27. DOI: <https://doi.org/10.5565/rev/analisi.3134>

\begin{abstract}
One possible way to learn from the social image of institutions, personalities and troubling issues in society may be provided by media discourse (Macedo and Cabecinhas, 2014; Carvalho, 2010). As such, this article tries to shed some light on the presence of community radio news in media discourse, measuring whether journalists tend to publish news or other informative content on these projects.

As community radios face countless contradictions all over Europe, from legal disparities to different perceptions of their social and economic value (Carpentier and Dahlgren, 2011), this observation seeks to identify what kind of issues are most likely to be reported in the media, as well as the unknown realities in which they are still immersed.

Using a textual analysis, this article provides insights into how community radio is regarded by the European media, from a multi-level sample of more than 100 news items, in different countries. Results show that community radio is more likely to be on the news in countries where this sector is properly regulated. As stated by the analysis, news tends to focus on European community radio situations and is less inclined to discuss the legal or social aspects of public participation in these media outlets.
\end{abstract}

Keywords: community; radio; news; media; coverage; Europe; regulation

Resum. Cobertura informativa sobre les ràdios comunitàries en els mitjans europeus: temes més destacats $i$ els que romanen en el silenci

Una de les maneres adequades d'entendre la imatge social de les institucions, les personalitats i els temes més importants per a una societat exigeix l'observació del discurs mediàtic (Macedo i Cabecinhas, 2014; Carvalho, 2010). Aquest article busca identificar els 
continguts que s'han publicat en els mitjans periodístics sobre el tema de les ràdios comunitàries per avaluar la presència d'aquest tema en el discurs periodístic.

No obstant això, les ràdios comunitàries viuen en un ambient totalment paradoxal a Europa, amb diferents percepcions sobre la utilitat que tenen aquests mitjans de comunicació, així com les formes de regulació legal d'aquests projectes en el mateix marc territorial (Carpentier i Dahlgren, 2011). Aquest treball analitza la projecció mediàtica de les ràdios comunitàries en el discurs periodístic avaluant les temàtiques més comunes, com també les que queden silenciades.

A partir d'una anàlisi textual amb més de cent articles periodístics de diferents mitjans de comunicació generalistes europeus, aquest article conclou que les ràdios comunitàries són un tema que apareix més als països on aquests projectes estan assenyalats i permesos per la llei. S'arriba a la conclusió que els exemples tractats en les notícies pertanyen al continent europeu i no s'incideix tant en els aspectes socials o legals de la repercussió social d'aquests mitjans.

Paraules clau: comunitat; ràdio; notícies; cobertura mediàtica; Europa; regulació

Resumen. Cobertura informativa sobre las radios comunitarias en los medios europeos: temas más destacados y los que permanecen en el silencio

Una de las maneras adecuadas de entender la imagen social de las instituciones, las personalidades y los temas más importantes para una sociedad exige la observación del discurso mediático (Macedo y Cabecinhas, 2014; Carvalho, 2010). Este artículo busca identificar los contenidos que se han publicado en los medios periodísticos sobre el tema de las radios comunitarias para evaluar la presencia de este tema en el discurso periodístico.

Sin embargo, las radios comunitarias viven en un ambiente totalmente paradójico en Europa, con diferentes percepciones sobre la utilidad que tienen estos medios de comunicación, así como las formas de regulación legal de dichos proyectos en el mismo marco territorial (Carpentier y Dahlgren, 2011). Este trabajo analiza la proyección mediática de las radios comunitarias en el discurso periodístico, evaluando las temáticas más comunes, así como las que quedan silenciadas.

A partir de un análisis textual con más de cien artículos periodísticos de diferentes medios de comunicación generalistas europeos, este artículo concluye que las radios comunitarias son un tema que aparece más en los países en donde dichos proyectos están seńalados y permitidos por la ley. Se llega a la conclusión de que los ejemplos tratados en las noticias pertenecen al continente europeo y no se incide tanto en los aspectos sociales o legales de la repercusión social de dichos medios.

Palabras clave: comunidad; radio; noticias; cobertura mediática; Europa; regulación

\section{Enthusiastic assumptions and divergences in the definition of "community radio"}

The very first experience of a community radio broadcaster happened during a coal miners' strike in Bolivia, in 1940 (Peruzzo, 1998). In Europe, it took almost two decades for the initial experiment to become a reality, as "some sources refer to Denmark's Radio Mercury as one of the first pirate stations to offer a programme-mix of current affairs and popular music" in 1960 
(Kern European Affairs, 2007: 22). The widespread boom of pirate radios in this continent in the 1970's (Kaplún, 1990) was the driver for the emancipation of countless community-driven radio experiences in Europe. Practitioners were motivated by the desire for free speech, because some social groups were not very happy with the media representation of reality, and thus demanded new forms of communicative expression, far removed from large media corporations and their interests (Guattari, 1982). In Europe, a generalized process of media liberalization took place during the 1980's, ranging from private to public stations, including some clandestine ones, such as pirate radios. This trend was especially widespread in the wake of the paradigmatic episode concerning Radio Caroline, in the 1960's, where legal disputes over licences were at stake.

In more recent years, different social and political perceptions of the role of community radio have stalled the evolution of these broadcasters, framing them as examples of a Third Media Sector, after public and private ones. There are still paradoxes regarding key aspects such as regulation, funding and social relevance. Notwithstanding such a complex landscape, according to a European-wide media report by the European Commission in 2007, "in the past two decades the Community Media sector has experienced more support from governments in North-Western European countries, such as the Scandinavian countries, than in the South-West of Europe" while "in the South-West of Europe, as is the case in Spain and Portugal, the sector has had to struggle harder for recognition and developed bottom-up" (Kern European Affairs, 2007: 22). Cankaya et al. (2008) included other types of menace: "the threats posed by commercialization and the increased penetration of commercial networks at the local level, and tensions in community radio practice" (2008: 87). It is also crucial to determine the social dimension of such projects. Building an audience, engaging people to participate in broadcasting and gathering volunteers from among amateurs and activists are also decisive aspects to be considered in a community radio start-up plan (Ribeiro, 2014). Furthermore, according to Doliwa and Rankovic (2014), there are several plausible explanations for the real emancipation of community radios, ranging from lack of political initiative to adjust the Media Law, little voluntary involvement and limited social knowledge about its possible benefits, to the restricted spectrum occupied by the commercial and public sector. Despite these troubling issues, there are no signs of retraction among community radio projects. According to a 2012 report by the Community Media Forum Europe, there are a growing number of more than 2,000 community radios in Europe in what appears to be the latest effort to make a count of such projects.

In academia, we can also appreciate growing interest among scholars in the issue of community radio (media), for instance, in the exact definition of these communicative experiences. In a 2005 Le Monde interview, Hubert Allouche, a former founder of Radio Aviva, a local and independent radio in Montpellier, said that he was "totally against" the terminology of "communi- 
ty radio" ${ }^{1}$. He claimed that the notion of "community" was limited, as Radio Aviva worked alongside more than 50 associations, not just one in particular. As López already pointed out in 1995, in Brazil the emancipation of these dynamics was initially recognised as "free radios", like the ones that were created in the 1970's in France, in Nicaragua as "participative radios" and in Ecuador as "popular radios" (Guattari, 1982). Nevertheless, it is assumed that "community radio" is the most recognisable concept. Bailey et al. considered that "in Africa, they refer to local rural radio, while in Europe the terms associative radio, free radio, popular free radio, neighbourhood radio, alternative radio and community radio are used. Asians speak of radio for development and of community radio; in Oceania the terms aboriginal radio, public radio and community radio are used" (2003: 6-7).

On the social dimension of community radio there is also highly prolific literature, as researchers have been assessing the potentialities of this media. However, Foxwell et al. "romanticised media" is a very accurate point of view: "[there is a] temptation to romanticise the sector and its efforts in terms of a grand political statement, a revolution against the nefarious impacts of globalisation and the profit-motives of transnational media corporations" (2008: 9). This is probably a similar idea to Simon Order's provocative - yet stimulating - question: "The Altruism of Community Radio?" (2013). Doubts on the positive social aspects of these broadcasters may persist, but it is probably the most common area in which researchers have decided to focus their perspectives when studying the community radio sector. In research into the sentimental dimension of working for community radios, Milan (2008) found several affective strings: "a free space for expression and self-determination (...) tool for social change (...) a political tool to involve and affect listeners (...) a voice amplifier with a transformative impact (...) serving other social groups (...) an empowering tool (...) a collective experience (...) a community revitaliser" (Milan, 2008: 28). This interpersonal dimension of community radio is also part of several approaches in the literature. In Taylor \& Francis' Journal of Radio \& Audio Media, applied research on specific contexts has been carried out in recent years. Martín and Matos (2013) in Bolivia, Torres (2011) in Brazil, Olorunnisola (2009) in South Africa or even Poindexter (2009) in France, to name just a few examples.

One key element to understand these projects is the presence of a certain degree of localism. Researchers have also been highlighting community media movements as fundamental to the survival of the niche, the unrepresented voices and marginalized groups. But localism is not only related with a geographical determination. As Vazquez (2001) points out, "local communication" is more about a general feeling towards a media, a personal experience that depends on the technological features to expand the dialogue and contact among peers. As such, Foxwell et al. indicate that community radio

1. Retrieved from <http://www.lemonde.fr/import/article/2005/08/13/en-region-huit-radios-en-prise-sur-la-vie-de-la-cite_679974_3544.html\#JybUyLuPCoUOCWiU.99>. 
could be a "cultural resource - a concept which refers to the capacity of these stations and their (mostly) volunteers to provide a space for the representation and communication of a multitude" (2008: 6).

That being said, there is an intention to observe the social image of community radio from its own representations on the news in different European countries. Following McQuail's (2003) assessment that media are only one of the main influencers of todays' interpersonal experience, this article is drawn upon the belief that media institutions are decisive for awareness/disregard towards a specific dimension of social life. As Moscovici (1961/1976) once defined in the Social Representations Theory, media representation is a potential element to suggest behaviours, beliefs and attitudes. Cabecinhas et al. (2011) indicated that media framing is also a key factor for balancing a positive or negative feeling regarding an object, in what Macedo and Cabecinhas (2014) described as "social nature of memory": "social interactions in which specific interpretations of events are highlighted, shared, negotiated, and contested, leading to fluid, dynamic representations of the events of our lives and helping us to define ourselves" (2014: 56).

As such, one possible way to understand the social value of community radio can be provided by an analysis of media content on this very topic. This is actually a typical tool in the field of Communication Sciences: in migration related issues (Macedo and Cabecinhas, 2012), educational policies (Pereira et. al, 2015) and climate change endeavours (Carvalho and Burgess, 2005).

\section{Community radio in the news: methodological options}

Research tools were implemented to give insights into several questions: what kind of news on community radio can be found in the mainstream press? What kind of personalities, issues and geographical contexts are explored by the media, when it comes to reporting on community radio?

As background information, it is possible to identify the actual state of community radio legislation in Europe according to multiple sources of information. Countries tend to name "community radio" in different terms, which comes as a troubling issue, as already stated. This situation can be identified in the legal regulation of the sector. Notwithstanding these multiple interpretations, the Media Pluralism Monitor ${ }^{2}$, an annual special report made by the European University Institute, provides important information. The importance of the original work put forward by Miriam Meda (2014), in her PhD thesis, is also a valuable resource to assess these regulatory determinations. Bearing in mind these decisive documents, a table was constructed to systematize how community radios are legally perceived in European Union countries.

2. Available at $<$ http://monitor.cmpf.eui.eu/mpm2016/>. 
Table 1. Legal status of community radio in the 28 European Union countries. Last update: January 2018

\begin{tabular}{|c|c|c|}
\hline Country & Legal status & Observations \\
\hline Austria & None & Although some community projects can get funding \\
\hline Belgium & Partial & Only in the francophone area \\
\hline Bulgaria & None & \\
\hline Croatia & Yes & \\
\hline Cyprus & None & \\
\hline Czech Republic & None & \\
\hline Denmark & Yes & \\
\hline Estonia & None & Only allows "radio amateurs" \\
\hline Finland & Yes & \\
\hline France & Yes & \\
\hline Germany & Yes & States can adapt the legislation \\
\hline Greece & None & \\
\hline Hungary & Yes & \\
\hline Ireland & Yes & \\
\hline Italy & Yes & \\
\hline Latvia & None & Although some community projects can get funding \\
\hline Lithuania & Yes & \\
\hline Luxembourg & None & \\
\hline Malta & Yes & \\
\hline Netherlands & None & \\
\hline Poland & Yes & \\
\hline Portugal & None & \\
\hline Romania & Yes & \\
\hline Slovakia & Yes & \\
\hline Slovenia & Yes & \\
\hline Spain & Yes & States are responsible for executing the law \\
\hline Sweden & Yes & \\
\hline United Kingdom & Yes & \\
\hline
\end{tabular}

The analysis of different practises shows three levels of legal recognition of community radios: full regulation (17 out of 28 considered), as countries properly define a space in the Media Law for the creation of community radio projects; 10 countries with no legal framework for community radio; and only one with partial legislation, which is the particular case of Belgium, where only the francophone area has this legal permission. Map 1 offers a visual understanding of these differences in terms of regulations.

From a superficial approach, the panorama seems to be a very optimistic one, since the majority of the countries have legal mechanisms to recognise community radios in Media Law. Only 10 countries have no such understanding and only one is doubtful, as partial recognition was acknowledged. 
Map 1. Legal regulation of community radio in the 28 European Union countries

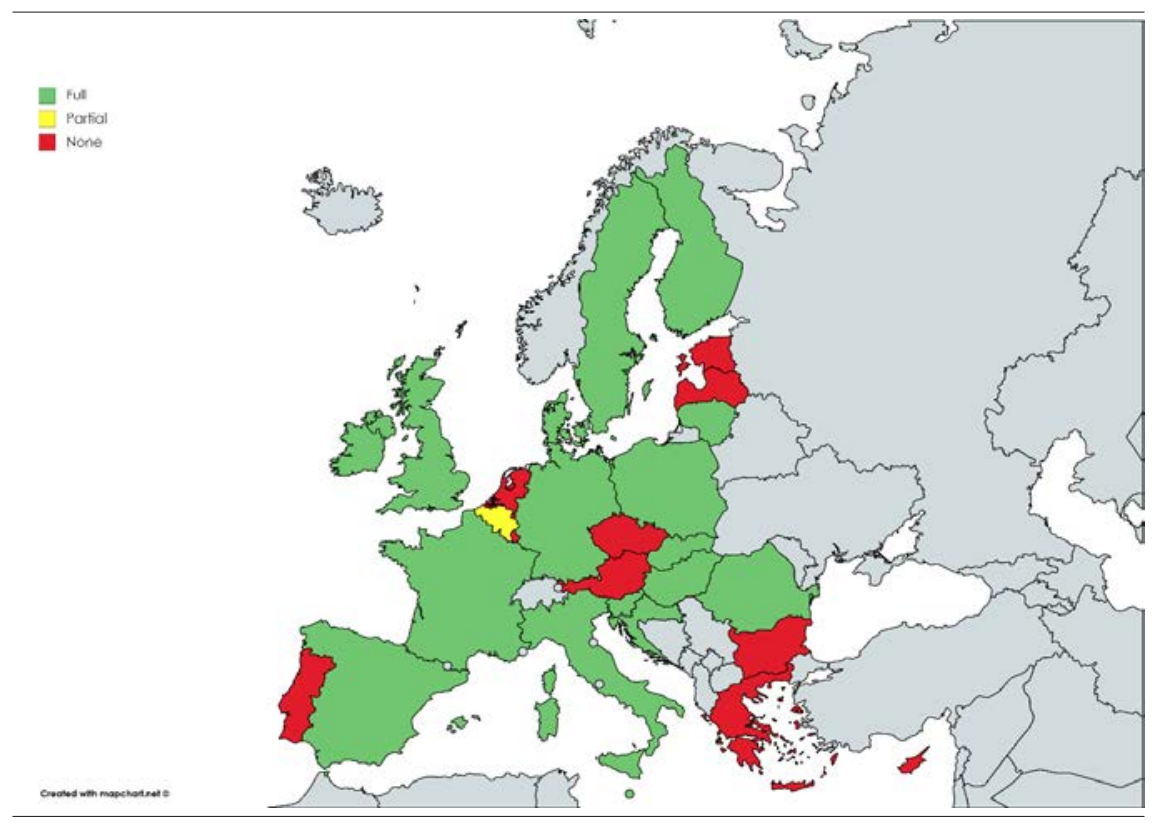

Source: Author's creation using Mapchart.net.

The second step of the methodological process was to analyse the media coverage of community radios. A sample was created based on the following criteria: 1) countries with regulation of community radio (United Kingdom, France and Italy), as well as those which do not possess the same legal instrument (Portugal, Austria and Latvia); 2) media news analysis, from the online archives of some of the most important media in the countries regarded in the latter criteria, according to two types of mass media communication (radio and press) and a solid and historical background in the field. News was observed in the online versions of newspapers and radios. Thus a content analysis was implemented, using NVivo software, which embodies both a qualitative and quantitative methodological approach. This analysis was focused to determine the content published over the years, the most common issues, personalities and institutions regarded by the media, the types of news and the countries/continents that are most represented in the news. As a starting point for this observation, Table 2 identifies the complete range of evaluation criteria, taking into account the research questions.

As mentioned before, this research supports the belief that media can be decisive for social representations of reality. Press and radio can objectively be relevant tools for understanding how community radio is portrayed by the media. Although other choices could be made, in terms of the sample selec- 
Table 2. News about community radio in the sample of countries, organized by type of media (radio and press) and legal framework

\begin{tabular}{|c|c|c|c|c|c|c|}
\hline \multicolumn{7}{|c|}{ Countries with Community Radio legislation } \\
\hline & \multicolumn{3}{|c|}{ Press } & \multicolumn{3}{|c|}{ Radio } \\
\hline & Title & $\mathrm{N}^{\circ}$ Title & $\mathrm{N}^{\circ}$ & Title & $N^{\circ}$ Title & $\mathrm{N}^{\circ}$ \\
\hline UK & The Guardian & 31 Daily Mail & 0 & BBC Radio 4 & 0 BFBS Radio & 5 \\
\hline France & Le Monde & 24 Le Figaro & 4 & $R T L$ & 4 France Info & 0 \\
\hline Italy & La Repubblica & 16 Corriere della Sera & 2 & Rai UNO & 0 Radio 24 & 1 \\
\hline News (type of media) & & 71 & 6 & & 4 & 6 \\
\hline Overall news & & & & & & \\
\hline
\end{tabular}

\begin{tabular}{|c|c|c|c|c|c|c|}
\hline \multicolumn{7}{|c|}{ Countries with no Community Radio legislation } \\
\hline & \multicolumn{3}{|c|}{ Press } & \multicolumn{3}{|c|}{ Radio } \\
\hline & Title & $\mathrm{N}^{\circ}$ Title & $\mathrm{N}^{\circ}$ & Title & $\mathrm{N}^{\circ}$ Title & $\mathrm{N}^{\circ}$ \\
\hline Portugal & Público & 7 Jornal de Notícias & 0 & Renascença & $3 \mathrm{TSF}$ & 2 \\
\hline Austria & Der Standard & 1 Kronen Zeitung & 1 & ORF & 0 Liferadio & 0 \\
\hline Latvia & Latvijas avīze & 0 Diena & 0 & LR1 & $0 L R 2$ & 0 \\
\hline News (type of media & & 8 & 1 & & 3 & 2 \\
\hline Overall news & & & & & & \\
\hline
\end{tabular}

Overall by media

Overall news

86

101

15

Source: Author's creation.

tion, it was our understanding that we should define public and private media institutions that are well-established and undoubtedly important in their countries, whether in terms of their historical path, audience rates or social credibility. In this sense, the period of examination encompasses an overall timeline of five years (2011-2016) ${ }^{3}$.

Global data analysis indicates that 24 media published an overall amount of 101 news items on community radio issues. For such a wide temporal gap, this is almost certainly a very limited number of news pieces and hence some conclusions may be assessed. The previous table clearly indicates that countries with legal regulation of community radios are the most likely to promote media coverage of these broadcasters, in 87 news items. In countries with no legal status, only 14 news items were collected. This proves a direct correlation between legal status and media coverage. If countries, as stated by the sample, have a legal background for the community radio sector, news is more likely to be published on the subject. In terms of the specific type of media, the press publishes more news content on community radio than

3. For statistical reasons, we decided to widen this temporal gap, in order to obtain more data and news. This was the case of Le Monde, La Repubblica, Corriere della Sera and Público. The whole news archive was observed. 
Chart 1. Date of the news items analysed

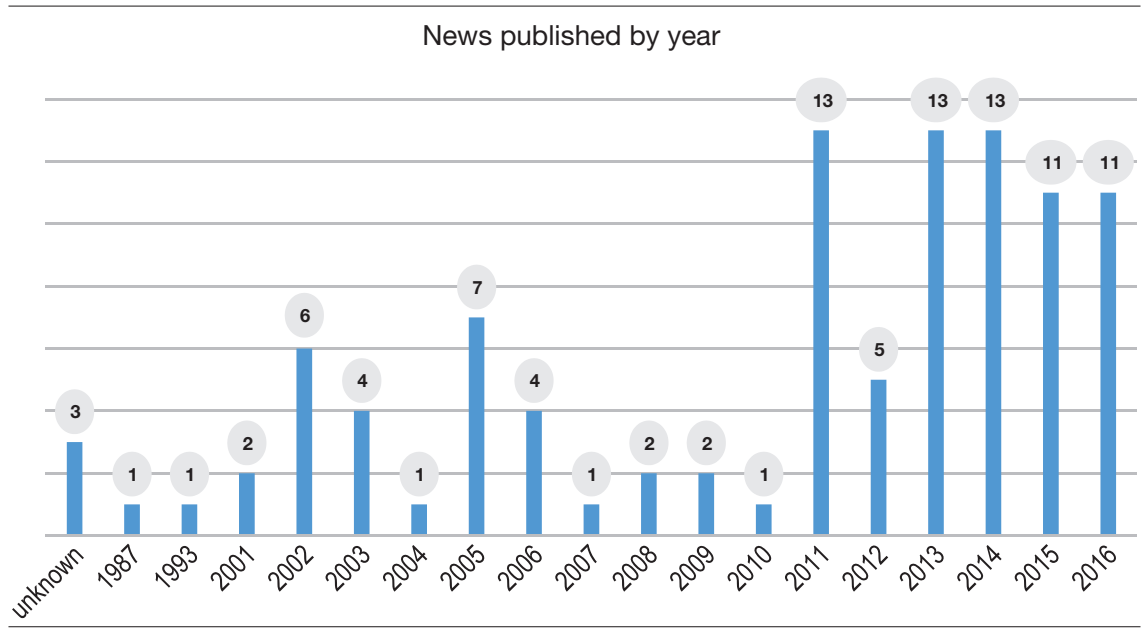

Source: Author's creation.

radio does: 86 news items $(85.1 \%)$ in the press, as opposed to only 15 on the radio $(14.9 \%)$. This evidence indicates that radio is less keen to talk about itself or other similar media than the press is.

Moving onto an analysis of this news, the first item to be considered was the data on news pieces, as shown in Chart 1.

The main timeframe of the study - five years of observation - shows that a steady but limited amount of content has been published. The evolution of these news publications was also very limited, ranging from 5 to 13 , at the most. There is no consistency in the annual number of published items, although in the period from $2011-2016$ it is possible to determine an increasing value of community radio content.

In terms of the content genre in the news, three main categories were observed:

Table 3. Content genre in the observed material

\begin{tabular}{lcc}
\hline Category & Frequency & $\%$ \\
\hline News & 45 & 44.55 \\
Opinion & 4 & 3.96 \\
Feature articles (stories) & 52 & 51.49 \\
Total & 101 & $100 \%$ \\
\hline
\end{tabular}

Source: Author's creation.

Opinion making on community radio is not a common feature. Commentators do not seem to be attracted to this subject. However, feature articles (stories) dominate (52 in 101) in this sense. Journalists tend to develop 
Table 4. News categories in content published on community radio

\begin{tabular}{lcc}
\hline Category & Frequency & $\%$ \\
\hline Empowering people in social matters & 41 & 40.59 \\
Community radio as a news source & 15 & 14.85 \\
Threats to community radio & 14 & 13.86 \\
New community radio & 7 & 6.93 \\
Community radio achievements & 6 & 5.94 \\
Community radio programming & 4 & 3.96 \\
Sanctions on community radio & 4 & 3.96 \\
Politics - takeover of community radio & 3 & 2.97 \\
Community radio and innovation & 2 & 1.98 \\
Legal issues regarding community radio & 2 & 1.98 \\
Dynamics within community radios & 1 & 0.99 \\
Community radio and technical support & 1 & 0.99 \\
Worthless community radio & 1 & 0.99 \\
Total & 101 & $100 \%$ \\
\hline
\end{tabular}

Source: Author's creation.

stories and narratives about this dimension of social reality. The provision of news about community radio is also highly relevant, with most of these items emerging as a consequence of new broadcasting stations or censorship episodes (the one with Marine Le Pen, when a French community radio refused to allow her to take part in a debate).

Apart from the content genre, one of the most important questions of this study concerns the actual subjects framed by community radio news. Table 4 was designed to summarise the most expressive categories within the news items analysed.

Three main categories were observed in the content analysis. According to this sample, community radio content in the media deals with empowering actions on the radio waves, thus affecting some social movements, in almost half of the news items observed (41). This may represent a logical consequence of the social dimension of these projects, which is strongly connected with groups and communities. In the news, the effects of such media were noted on the Algerian, African, black and Jewish communities, as well as on health campaigns. The second category suggests the idea of community radio as a news source for other media. It is noted that this number was particularly expressive after the refusal by a French community radio to host Marine Le Pen in a debate with a Jewish community. The third most observed category - 14 news items - highlights the constant threats to community radio stations worldwide, mainly in South America, where a radio host was killed and an ambush occurred. Most of these situations were affronts to freedom of speech, seeking to intimidate radio practitioners in the ongoing pursuit of social changes. As a final remark on this matter, the diversity of subjects regarding community radio, including licences for new com- 
Table 5. Main figures reported on in community radio content

\begin{tabular}{lcc}
\hline Category & Frequency & $\%$ \\
\hline Society in general & 65 & 64.36 \\
Community radio exclusively & 19 & 18.81 \\
Government & 10 & 9.9 \\
Other politicians & 5 & 4.95 \\
Media in general & 1 & 0.99 \\
Public Relations & 1 & 0.99 \\
Total & 101 & $100 \%$ \\
\hline
\end{tabular}

Source: Author's creation.

munity radio stations (mainly in the UK and Australia), sanctions and legal issues can be acknowledged.

Community radio content often highlights certain personalities, groups or institutions, for instance. Table 5 indicates the type of figures that are most commonly represented.

The strategic placement of society in the community radio context has already been mentioned, and this matter is also widely reported in this observation. News items tend to demonstrate how community radio might suggest social improvements in areas such as cultural expression and health awareness. Society was at the core of the media coverage in 65 cases. This table also shows the intriguing aspect whereby, as legal determinations are often the main topic and argumentation with regard to the third sector, it is surprising that such limited attention was given to politicians or governments. These are the main actors that theoretically decide on specific media regulations, yet no substantial media coverage was found to cover this subject.

The final observation criteria focused on the geographic references within texts, as a way to understand what kind of countries are most represented in media discourse. Table 6 indicates the overall distribution.

The distance between the three most cited countries - UK (20), France (19) and Italy (14) - and the other 26 mentioned is substantial. Taking into account that geographical proximity is a decisive news value, it is probably only to be expected that European media should focus their coverage within their own borders. Considered by continents, the same data is shown in Map 2.

The differences in media coverage can be visualized in terms of continents: 55 news items from Europe, then America (15), Africa (14), Oceania (5) and Asia (4). It is somewhat surprising to conclude that America - especially South America - and Africa, with such long, profound and historical traditions of community radio, have little presence in the media.

\section{The silence of news: final remarks}

An overall analysis of this observation indicates very clearly that media are considerably self-centred on their countries and close realities. Their perspec- 
Table 6. Countries and locations reported in the community radio content

\begin{tabular}{lcc}
\hline Country & Frequency & $\%$ \\
\hline UK & 20 & 19.80 \\
France & 19 & 18.81 \\
Italy & 14 & 13.86 \\
Australia & 5 & 4.95 \\
Brazil & 4 & 3.96 \\
Guinea Bissau & 3 & 2.97 \\
Ecuador & 2 & 1.98 \\
India & 2 & 1.98 \\
Peru & 2 & 1.98 \\
Tunisia & 2 & 1.98 \\
Venezuela & 2 & 1.98 \\
Afghanistan & 1 & 0.99 \\
Argentina & 1 & 0.99 \\
Austria & 1 & 0.99 \\
Bolivia & 1 & 0.99 \\
Chad & 1 & 0.99 \\
\hline
\end{tabular}

\begin{tabular}{lcc}
\hline Country & Frequency & $\%$ \\
\hline Congo & 1 & 0.99 \\
Honduras & 1 & 0.99 \\
Jordan & 1 & 0.99 \\
Kenya & 1 & 0.99 \\
Mozambique & 1 & 0.99 \\
Paraguay & 1 & 0.99 \\
Rwanda & 1 & 0.99 \\
Senegal & 1 & 0.99 \\
Sierra Leone & 1 & 0.99 \\
Somalia & 1 & 0.99 \\
South Africa & 1 & 0.99 \\
USA & 1 & 0.99 \\
Portugal & 1 & 0.99 \\
Unclear & 1 & 0.99 \\
Several countries & 7 & 6.93 \\
Total & 101 & $100 \%$ \\
\hline
\end{tabular}

Source: Author's creation.

tives tend to focus on their own reality within their own borders. Our results show that most media, when reporting on community radio related issues, tend to observe their own circumstances and experiences in the field. As such, countries with no regulation of this sector have little interest in the issue. Nevertheless, freedom of speech and access to information are still fundamental communication rights and countries face daily challenges in this area.

Map 2. Distribution, by continent, of the countries outlined by community radio news

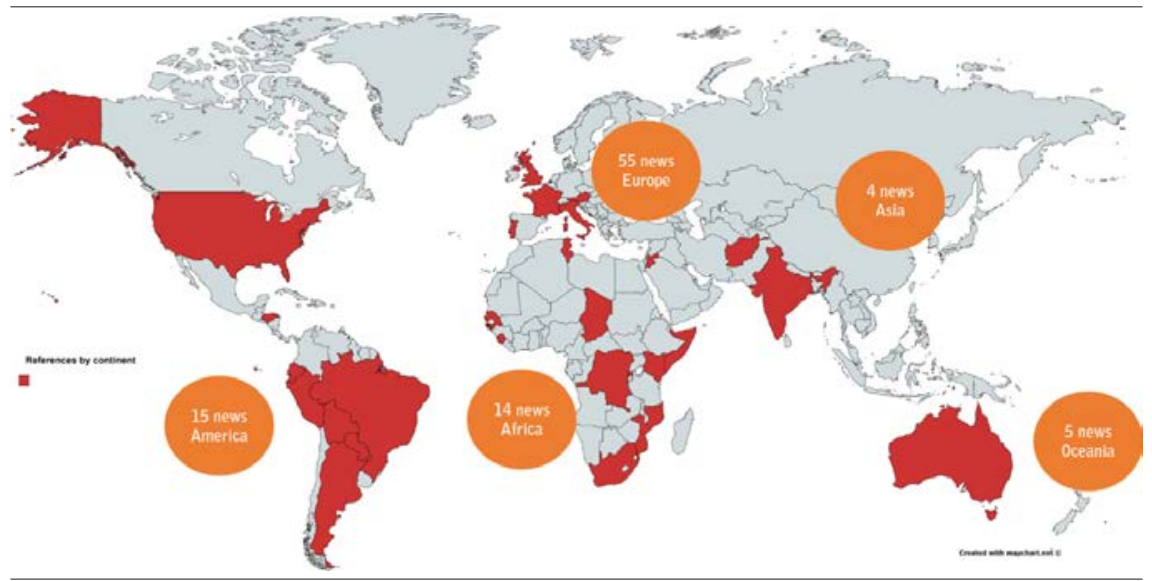

Source: Author's creation using Mapchart.net 
By promoting wider spaces for self-expression, in this kind of communication sector, governments and their legal bodies could enhance multiple opportunities in this regard. But according to our research, the legal framework of these radio projects remains doubtful.

Although other countries and media could be included in the sample, hence providing additional insight, it is also clear that the news agenda with regard to community radio involves troubling aspects. Scholars have been stressing the urgent need for legal adjustments, but mainstream media are neglecting this issue. Only two news items, out of 101, highlighted legal aspects. However, 41 news items observed the social potential of community radio, which conveys a highly auspicious ambition of this media. News and stories are the most common types of media content in this observation, with no interviews regarded. Opinion makers also ignore the issue. Our conclusions also advocate that mainstream radio is silent on community radio, as opposed to the press, which is more active in the publication of information about this type of media.

Notwithstanding the traditional and social relevance of community radio in Asian, South American and African countries, as often highlighted by academics (Kaplún, 1990; Olorunnisola, 2009), it seems that such examples are not covered by the media either. International news and reports tend to observe diverse items worldwide, but little attention is dedicated to this issue. Following the same pattern of media silence, it is also surprising to note that journalists do not interact with governmental bodies when it comes to analysing these issues. Community radio news tends to focus on the personalities working in this area of broadcasting, underlining their constraints and daily routines. Even though legal aspects are considered, no official entities are shown to comment on the subject.

Community radio scholars often share a certain enthusiasm for the social potentialities of this media, which strongly coincides with observations of most media coverage of this subject. As Milan (2008) pointed out, self-satisfaction is also a very common feeling among community radio practitioners and volunteers. Future research shall continue to observe this sentimental dimension of a media platform that is still immersed in an unknown landscape. However, it seems clear that there are positive and solid social endeavours to enhance community development across the radio waves. Scientific approaches have been conducted to highlight the impact of such projects in the world, and feature articles present identical perspectives.

For academics, there is almost consensus about the idea of community radio, but critical approaches have yet to be seriously undertaken. There has been little effort to constantly map these projects, while on a broader level a permanent observatory of community radio projects should also be considered. Monitoring agents, underlining key organisms and societal dynamics, undermining constraints and restrictions and also providing basic support for the community should be the main concerns in the upcoming years. The social image of these radios is also highly dependent on these efforts. 


\section{Bibliographical references}

Bailey, O.; CAmmaerts, B. and CARPentier, N. (2007). Understanding Alternative Media. New York: Open University Press.

CAmmaerts, B. (2009). "Community radio in the west: A Legacy of Struggle for Survival in a State and Capitalist Controlled Media Environment”. The International Communication Gazette, 71 (8), 635-654.

CANKAYA, O.; GÜNEY, H. and KÖKSALAN, M. (2008). "Turkish radio broadcasts in The Netherlands: Community Communication or Ethnic Market?”. Westminster Papers in Communication and Culture, 5 (1), 86-106.

CARPENTIER, N. and DAHLGREN, P. (2011). "Interrogating audiences: Theoretical horizons of participation". Communication Management Quarterly, 21 (VI), 7-12.

Carvalho, A. and Burgess, J. (2005). "Cultural circuits of climate change in U.K. broadsheet newspapers, 1985-2003". Risk Analysis, 25 (6), 1457-1469.

DOLIWA, U. and RANKOVIC, L. (2014). "Time for community media in Central and Eastern Europe". Central European Journal of Communication, 1, 18-33.

Foxwell, K.; EWART, J.; Forde, S. and MEADOWS, M. (2008). "Sounds like a whisper Australian Community Broadcasting hosts a quiet revolution". Westminster Papers in Communication and Culture, 5 (1), 5-24.

GUATTARI, F. (1982). Las radios libres populares. In: L. BASSETS (ed.). De las ondas rojas a las radios libres. Barcelona: Gustavo Gili, 231-236.

KAPLÚN, M. (1990). Comunicación entre grupos. Buenos Aires: Hvmanitas.

KERN EUROPEAN AFFAIRS (KEA) (2007). The state of community media in the European Union. Brussels: Policy Department Structural and Cohesion Policies European Parliament. Retrieved from: <http://cmfe.eu/docs/1166366638_ The $\% 20$ state $\% 20$ of $\% 20$ community $\% 20$ media.pdf $>$.

LOPEZ, V. (1995). “¿Qué hace comunitaria a una radio comunitaria?”. Chasqui, 52, 51-54.

Macedo, I. and Cabecinhas, R. (2014). "Diasporic identity(ies) and the meaning of home in autobiographical documentary films". Revista Lusófona de Estudos Culturais, 2 (1), 54-71. Retrieved from: <http://repositorium.sdum.uminho.pt/bitstream/1822/29894/1/IM_RC_RLEC_EN.pdf $>$.

Martín, J. and Matos, A. (2013). "Public Policy and Community Radio in Bolivia”. Journal of Radio \& Audio Media, 20 (2), 251-272.

MCQUAIL, D. (2003). Teoria da comunicação de massas. Lisboa: Fundação Calouste Gulbenkian.

MEDA, M. (2014). El tratamiento de los medios comunitarios en el marco de la ley general de la comunicación audiovisual. PhD Thesis. Madrid: Complutense University of Madrid.

Milan, S. (2008). "What makes you happy? Insights into feelings and muses of community radio practitioners". Westminster Papers in Communication and Culture, 5 (1), 25-43.

Olorunnisola, A. (2009). "Community Radio: Participatory Communication in Postapartheid South Africa”. Journal of Radio Studies, 9 (1), 126-145.

Order, S. (2013). "The Altruism of Community Radio?". Asia Pacific Media Educator, 23 (2), 381-401.

Pereira, S.; Pereira, L. and Melro, A. (2015). "The Portuguese programme one laptop per child: political, educational and social impact”. In: S. PEREIRA (eds.). Digital literacy, technology and social inclusion: making sense of one-to-one computer 
programmes around the world. Braga: Universidade do Minho. Centro de Estudos Humanísticos (CEHUM), 29-100. Retrieved from: <http://repositorium.sdum. uminho.pt/bitstream/1822/40835/1/SP_LP_AM_2015_digital_literacy.pdf>.

Peruzzo, C. (1998). Participação nas Rádios Comunitárias no Brasil. Retrieved from <http://www.bocc.ubi.pt/pag/peruzzo-cicilia-radio-comunitaria-br.pdf>.

PointDeXTER, M. (2009). "Radio in Madagascar: Pluralism in an Economically Underdeveloped Country”. Journal of Radio Studies, 8 (1), 175-190.

Torres, B. (2011). Community Radio Stations in Brazil. Journal of Radio \& Audio Media, 18, 347-357.

VAZQUEZ, A. I. (2001). Os Informativos diários nas televisións locais de Galicia. A información televisiva no espacio local. Phd Thesis, Santiago de Compostela, University of Santiago de Compostela, Spain. 
